YAK $347.122(477)$

DOI https://doi.org/10.32837/chc.v0i35.183

Аеревнін Володимир Сергійович,

кандиАат юриАичних наук, Аоцент кафедри цивільного права

Національного університету "ОАеська юридична академія"

\title{
ПОНЯТТЯ, ОЗНАКИ Й ОСОБЛИВОСТІ ПРАВОВОЇ ПРИРОДИ IНТЕРЕСУ В ЦИВІЛЬНОМУ ПРАВІ
}

Постановка проблеми. Розуміння інтересу в цивільному праві як юридичної категорії неможмиво без визначення його правової природи і правового режиму. Спірним $є$ питання про правову природу інтересу, а саме: $є$ інтерес явищем суб'єктивним або він за своєю природою об'єктивний. Наявна неоднозначність щодо "права". Законодавець точно вказав, що воно "громадянське", а щодо категорії "інтерес" позиція не така однозначна (ст. ст. 15-17 Цивільного кодексу України (Аалі - ЦКУ)) [1]. Незважаючи на те що проблеми, пов'язані із цією категорією, мають методологічне значення Аля науки цивільного права, єАиний піАхіА АО юриАичного інтересу Ао сих пір не вироблений.

Стан АосліАження теми. Основу АосліАЖення становлять наукові статті та публікації таких авторів, як $Є$. Харитонов, А. Ткачук, А. Арішлюк, А. Гужва, В. Грибанов, А. Венедиктов, О. Первомайський, О. Чепісі.

Метою статті $€$ досліАження й вирішення наукових питань, пов'язаних із однозначним трактуванням як самого поняття "інтерес" у цивільному праві, так і його ознак, а також визначення основних напрямів Аослідження інтересу як категорії в праві.

ВикиаА основного матеріалу АосліАження з повним обгрунтуванням отриманих наукових результатів. Категорія інтересу $€$ насампереА питанням загального вчення про право. Інтерес відіграє провідну роль у виникненні, зміні та припиненні правовідносин. Без явного або передбачуваного інтересу не можуть виникнути правовіАносини. У Аеяких випадках закон прямо пов'язує Аолю правовіАносин з інтересом. У цьому випаАку можливість припинити зобов'язальні правовіАносини прямо пов'язується зі зниженням інтересу. Найбільш часто в науковій літературі Аискутується питання, вважати інтерес категорією суб'єктивною, об'єктивною або тою, що має подвійну сутність. Інтерес у загальній теорії права може розглядатися як феномен, що має об'єктивні й суб'єктивні характеристики [2].

Цієї точки зору Аотримуються в психічній налаштованості суб'єкта інтересу за аАресою будь-якого об'єкта (явища). Об'єктивна сторона інтересу полягає в Аеякій незалежності, віАособленості інтересу віА його суб'єкта. Тобто інтерес існує як факт навколишньої дійсності. Інтерес - це певна потреба в чому-небудь. Потреба породжує інтерес, стаючи його змістом. Отже, будучи первинною щодо інтересу, потреба керує інтересом. Інтерес $€$ сполучною ^анкою між різного роду благами й суб'єктивними правами. 3 приводу матеріального блага виникає майнове правовіАношення, його виникнення пов'язано з майновим інтересом. Аналогічно з нематеріальним благом. Немайновий інтерес може існувати в майновому правовідношенні й навпаки. НаприклаА, так званий сервітут Аає право правомочному майнове право, яке полягає в можливості надати сусіАові звоАити всякого роду споруди вище певної висоти, щоб вони не перешкоджали Аоступу сонячного світла й не затуляли виА. Цей сервітут обслуговує майнові потреби власника панівного нерухомого майна, але при цьому останній може мати суто нематеріальний інтерес (заАоволення віА гарного вигляду), що не входить у майнові правовідносини із сервітуту. Водночас інтерес - це більш широка категорія. Норми права обов'яз- 
ково виражають різні інтереси, наділення особи правоздатністю говорить про гіпотетичну можливість існування різних інтересів у правоздатної особи. Можливість установлення суб'єктивного права пов'язується з наявністю певного інтересу в його суб'єкта.

Поняття "правовий інтерес" ширше за поняття "охоронюваний законом інтерес", тому навряд чи правильно їх ототожнювати. Фактичний власник майна, віАповіАно Ао ст. 344 ЦКУ («Набувальна Аавність"), не перебуває до набуття права власності на це майно в правовідносинах абсолютного типу. ОАнак, захищаючи своє володіння проти третіх осіб, фактичний володілець захищає свій охоронюваний законом інтерес в очікуванні виникнення права власності. Отже, інтерес - це "наскрізна" категорія. Юридично значимий інтерес або покривається суб'єктивним правом, або виступає у формі «охоронюваного законом інтересу".

Різниця між суб'єктивним правом та інтересом - наслідок формально-юридичних причин. Суб'єкту інтересу може бути надана конкретна міра можливої поведінки з формально-юридичної позиції, що охоронюваний законом інтерес (законний інтерес; проявляє себе тоді, коли він порушений кимось). Отже, коли мова йде про охоронюваний законом інтерес, суб'єкту інтересу надається не міра можливої поведінки, а мише можливість захистити порушений інтерес у рамках охоронюваних правовідносин. Із цього випливає, що різниця між інтересом, покриваючим суб'єктивним правом та охоронюваним законом - тільки в правових засобах задоволення потреб. В одних випаАках Аля цього наАається міра можливої поведінки, в інших - Аосить тільки охорони. Звісно ж, у рамках правової системи соціальний інтерес трансформується в таке правове явище, як юридичний інтерес.

По-перше, мюдина не може реалізувати свої інтереси без залучення юридичних засобів.

По-Аруге, регульовані правом віАносини є віАносинами вольовими. У цьому аспекті інтерес може розумітися як стимул.

По-третє, інтерес, впливаючи на волю, виражену за Аопомогою волевиявлення, перетворюється в юридичну конструкцію, іменовану юриАичним інтересом.

Спірним $є$ питання про правову природу інтересу, а саме $\epsilon$ інтерес явищем суб'єктивним, що виражає відому психічну налаштованість суб'єкта, або він за своєю природою об'єктивний, тобто є певною об'єктивною умовою ^юАського існування [3].
Прихильники першої концепції (суб'єктивної) розглядають інтерес як суб'єктивне поняття, що відображає психічне ставлення суб'єкта Ао юриАичного блага. ОАнак особи з порушеною психікою також потребують певних соціальних умов, отже, мають свій інтерес, який визнається державою й береться піА правову охорону. Отже, реалізація інтересу може здійснюватися не тільки через свідомість, а й через учиненням вольових Аій.

Прихильники Аругої концепції (об'єктивної) розглядають інтерес як категорію об'єктивну, яка виникає поза свідомістю й волею суб'єкта. Це зумовлюється тим, що, по-перше, поява інтересів у суб'єкта визначається наявністю в нього потреб. По-Аруге, зміст інтересів зумовлено особливостями предмета потреби та процесу овомодіння ним у цих умовах. По-третє, реалізація інтересів пов'язана 3 подоланням об'єктивно існуючих перешкоА, із наявністю певних коштів, які вступають у взаємодію із суб'єктом. "Усякий інтерес - це інтерес певного суб'єкта, незалежно віА того, є таким суб'єктом окремий громадянин, група осіб або навіть суспільство. Але за такого розуміння інтерес ототожнюється 3 умовами життя ^юАей" [4].

Третя концепція (суб'єктивно-об'єктивна) розглядає інтерес як Авоїсту суб'єктивно-об'єктивну категорію. Тут інтерес являє собою психічне ставмення суб'єкта, що виражається певними Аіями, але зумовлену громадськими (об'єктивними) умовами життя суспільства. Цієї концепції Аотримується і Є. Харитонов. "ннтерес у загальній теорії права може розглядатися як феномен, що має об'єктивні й суб'єктивні характеристики" [5].

На підставі вищевикладеного можна зробити висновок, що правова природа інтересу багатогранна, найбільш вАалою концепцією природи інтересу є суб'єктивно-об'єктивна концепція, віАповідно Ао якої інтерес частково визначається й формується суспільними інтересами. А. Аріш^юк виділяє Ава випаАки вживання категорії інтересу в текстах римських юристів і сучасному цивільному праві, один із яких - особа прагне отримати або віАновити певне благо, що є метою й умовою Аійсності правовіАносин, наприклаА укладення Аоговору, подача позову (назвемо умовно інтерес у цьому випадку позитивним інтересом певної вигоди), проте не отримує це через порушення свого права, що є умовою Аля віАшкоАування збитків.

Можна погодитися 3 дефініцією авторів про об'єктивний і суб'єктивний інтерес, де об'єктивний 
інтерес фіксує заходи, зАійснення яких призвоАить Ао оптимального задоволення тих чи інших об'єктивних потреб, сприяє, у кінцевому підсумку, зміцненню й позитивній зміні соціального становища суб'єкта суспільних віАносин. Суб'єктивний інтерес являє собою відокремлені об'єктивними й суб'єктивними факторами віАносини конкретного суб'єкта Ао способів Аосягнення цієї мети та характеризується вибірковістю й вольовою спрямованістю [6].

Автори не заперечують як факт паралельного існування об'єктивних і суб'єктивних інтересів, так і їх значення Аля права. Якщо мова йде про правомірність поведінки тієї чи іншої особи, мається на увазі об'єктивний інтерес. Прикладом $€$ ч. 7 ст. 47 Конституції України [7]: “... використання власності не може завдавати шкоди правам, свободам та гідності громадян, інтересам суспільства, погіршувати екологічну ситуацію і природні якості землі".

А. Ткачук висловлює свою незгоду з точкою зору авторів, які вважають, що законні інтереси пов'язані тільки із ситуацією, що вимагає втручання держави, фактично ототожнюють задовомення законних інтересів 3 їх охороною (захистом), він уважає, що законні інтереси в більшості випадків можуть бути задоволені за недостатністю майна без втручання держави, тоді як охорона (захист) законних інтересів є лише однією з форм їх реалізації [8].

Визнання категорії "юридичний інтерес" юриАичною конструкцією тягне за собою обов'язків розгляА її як юриАичної форми.

«Юридична форма, по-перше, має безпосереАній зв'язок із нормами об'єктивного права, без припису яких не має права на існування, по-Аруге, передбачає встановлення єАиного масштабу повеАінки невизначеного кола осіб і, по-третє, встанов^ює межі можливої чи належної поведінки" [9].

у теорії цивільного права виділяються такі юридичні форми, як норми права, цивільні правовіАносини, юридичний факт, видається, що юридичний факт не може бути зарахований Ао жодної з перерахованих категорій і $€$ самостійною юридичною формою.
Поняття "охоронюваний законом інтерес" Аав Конституційний Суд України, точніше буде, не поняття, а ознаки цього феномена:

а) виходить за межі змісту інших засобів правової охорони;

б) має на меті задоволення усвідомлених індивіАуальних і колективних потреб;

в) Є самостійним об'єктом судового захисту й інших засобів правової охорони;

г) не може суперечити Конституції й законам України;

А) означає прагнення Ао користування конкретним матеріальним і нематеріальним благом;

е) розглядається як простий мегітимний дозвіл.

СуА піАкреслює, що поняття "Охоронюваний законом інтерес" у логічно-смисловому розумінні пов'язаний із поняттям "право" і має один і той же сенс [10].

Що стосується захисту інтересу, то в охоронюваного законом інтересу немає Аворівневого змісту, так як ця правова категорія, на відміну віА суб'єктивного права, не має у своєму склаАі будь-яких правочинів. Вони з'являються тільки в разі виникнення охоронюваних правовіАносин, коли охоронюваний законом інтерес уже порушено. Отже, зміст охоронюваного законом інтересу обмежується тільки фактичним інтересом. Порушений інтерес, звичайно ж, може захищатися в рамках охоронного правовідношення, інакше категорія охоронюваного законом інтересу втратила б будь-який сенс.

Висновки 3 АосліАження та перспективи подальших розвіАок у цьому напрямі. Отже, за результатами АосліАження можемо резюмувати таке:

Юридичний інтерес - це правовий зв'язок, який виникає між учасниками суспільних відносин на підставі правової ініціативи, що прояв^яєТься оАним Стосовно іншого, що очікує сприятливих юриАичних насліАків власної правової ініціативи у вигляді певного блага.

Юридичний інтерес забезпечує як формальну (правову) рівність, так і фактичну рівність (рівноправність).

\section{NITEPATYPA:}

1. Цивільний кодекс України. Відомості Верховної Ради України. 2003. № 40-44. Ст. 356.

2. Харитонов Є.О. Категорія інтересу в цивільному праві України. Актуальні проблеми держави і права : збірник наукових праць / редкол.: С.В. Ківалов (голов. ред.), Ю.М. Оборотов (заст. голов. ред.), Л.Р. Біла (відп. секр.) та ін. ; ОНЮА. Одеса : Юрид. л-ра, 2005. Вип. 25.

3. Грибанов В.П. Интерес в гражданском праве. Советское государство и право. 1967. № 1. С. 50.

4. Грибанов В.П. Интерес в гражданском праве. Осуществление и защита гражданских прав. 2-е изд., стереотип. Москва : ЮрИнфор, 2001. 212 с. 
5. Харитонов Є.О. Категорія інтересу в цивільному праві України. Актуальні проблеми держави і права : збірник наукових праць. 1994-2005. Вип. 25. С. 216.

6. Чепис О.І. Інтерес в цивільному праві: сутність, місце та особливості захисту : дис. ... канд. юрид. наук : 12.00.03. Ужгород, 2010. $230 \mathrm{c}$.

7. Конституція України : Закон України від 28 червня 1996 року. Відомості Верховної Ради України. 2014. № 11. Ст. 47.

8. Ткачук А.Л., Дрішлюк А.І. Цивільно-правовий захист охоронюваних законом інтересів. Актуальні проблеми держави $i$ права. 2003. Вип. 23.

9. Первомайський О. Поняття інтересу в цивільному праві та законодавстві. Юридична Украӥна. Журнал Київського національного університету ім. Тараса Шевченка. 2014. № 11. С. 54.

10. Рішення Конституційного Суду України від 01.12.2004 № 18-рп/2004. Офіиійиний вісник України. 2004. № 50. Ст. 3288.

\section{Аеревнін Володимир Сергійович}

\section{ПОНЯТТЯ, ОЗНАКИ Й ОСОБЛИВОСТІ ПРАВОВОЇ ПРИРОАИ ІНТЕРЕСУ В ЦИВІАЬНОМУ ПРАВІ}

Стаття присвячена аналізу поняття, характерних ознак, правової природи інтересу в цивільному праві. Визначено, що це правовий зв'язок, що виникає між учасниками суспільних відносин на підставі правової ініціативи. Юридичний інтерес як категорія забезпечує рівність як формального, так і фактичного його учасників. Як висновок установлено, що юридичний інтерес - це правовий зв'язок, який виникає між учасниками суспільних віАносин на основі правової ініціативи, що проявляється одним стосовно іншого, який очікує сприятливих юриАичних наслідків власної правової ініціативи у вигляді певного блага. ВідповіАно, юридичний інтерес забезпечує як формальну (правову) рівність, так і фактичну рівність (рівноправ'я).

Киючові слова: інтерес, правова система, юридичний інтерес, правова категорія, цивільне право.

\section{Аеревнин Владимир Сергеевич}

\section{ПОНЯТИЕ, ПРИЗНАКИ И ОСОБЕННОСТИ ПРАВОВОЙ ПРИРОАЫ ИНТЕРЕСА В ГРАЖААНСКОМ ПРАВЕ}

Статья посвящена анализу понятия, характерных признаков, правовой природы интереса в гражданском праве. Определенно, что это правовая связь, возникающая между участниками общественных отношений на основании правовой инициативы. Юридический интерес как категория обеспечивает равенство как формального, так и фактического его участников. Установлено, что юридический интерес - это правовая связь, возникающая между участниками общественных отношений на основании правовой инициативы, проявляемой одним в отношении Аругого, ожидающего благоприятных юридических послеАствий собственной правовой инициативы в виле определенного блага. Юридический интерес обеспечивает как формальное (правовое) равенство, так и фактическое равенство (равноправие).

Киючевые слова: интерес, правовая система, юридический интерес, правовая категория, гражданское право.

\section{Derevnin Vladimir}

\section{THE CONCEPT, FEATURES AND PECULIARITIES OF THE LEGAL NATURE OF INTEREST IN CIVIL LAW}

Abstract. The article is devoted to the analysis of the concept, characteristic features, legal nature of interest in civil law. It is determined that this is a legal relationship that arises between the participants in the relations on the basis of legal initiative. Legal interest as a category ensures the equality of both formal and actual participants. Interest can be considered as a phenomenon, which possesses objective and subjective characteristics in the general theory of law. Interest acts as a pivotal link between all sorts of benefits and subjective rights. The legal nature of interest is multifaceted; the most successful concept of the nature of interest is the subjective-objective concept, according to which interest is partly predetermined and shaped by public interests. Legal interest is a legal relationship that arises between participants of public relations on the basis of a legal initiative, manifested by one in relation to another, awaiting the favorable legal consequences of their own legal initiative in the form of a certain benefit.

It was established that the interest protected by law does not have a two-level content, since this legal category, unlike a subjective right, does not include any legal powers. They appear only when a protective legal relationship arises at the moment when the interest protected by law was already violated. Consequently, the content of interest protected by law is limited only by the actual interest. A broken interest can be defended within the framework of a protective relationship, otherwise the category of interest protected by law would lose all meaning. Author made a conclusion that legal interest is a legal relationship that arises within participants in public relations on the basis of a legal initiative, which is manifested by one in relation to another, who expects the favorable legal consequences of its own legal initiative in the form of a certain benefit. Legal interest provides both formal (legal) equality and actual equality (equality of rights).

Key words: interest, legal system, legal interest, legal category, civil law. 